\title{
Cryopreservation of mouse spermatozoa in the presence of raffinose and glycerol
}

\author{
N. Tada*†, M. Sato $\dagger$, J. Yamanoi†, T. Mizorogi*, K. Kasai* and S. Ogawa $\ddagger$ \\ *Section of Experimental Animal Administration and $\dagger$ Laboratory for Molecular Biology, \\ Pharma Research Laboratories, Hoechst Japan Limited, 1-3-2 Minamidai, Kawagoe, Saitama 350, \\ Japan; and $\$$ Laboratory of Animal Reproduction, Faculty of Agriculture, Meiji University, \\ 1-1-1 Higashimita, Tama-ku, Kanagawa 214, Japan
}

\begin{abstract}
Summary. When mouse epididymal spermatozoa were rapidly frozen in two steps ( 37 to $-70^{\circ} \mathrm{C}$ for solid $\mathrm{CO}_{2}$ and -70 to $-196^{\circ} \mathrm{C}$ for liquid nitrogen) as pellets, $18 \%$ raffinose provided the greatest protection to ICR mouse spermatozoa against cold-shock; sperm motility and fertilizing ability were $43 \%$ and $22.4 \%$, respectively. A small proportion of spermatozoa frozen with $10 \%$ sucrose was motile but incapable of fertilizing ovulated oocytes. Glycerol and dimethylsulphoxide were less effective at any concentration examined. However, the fertilizing ability of frozen-thawed ICR spermatozoa was significantly improved $(35.5 \%)$ by addition of glycerol $(1.75 \%$ final concentration) to medium containing $18 \%$ raffinose. Spermatozoa from one outbred (ddY) and 5 inbred (C57BL/6N, C3H/HeN, DBA/2N, BALB/c and kk) strains of mice were successfully frozen in the presence of $18 \%$ raffinose and $1.75 \%$ glycerol, although the fertilization rates of frozen-thawed spermatozoa varied among strains $(13 \%$ for C57BL/6N to $64 \%$ for DBA/2N). A small fraction of mouse eggs resulting from fertilization by frozen-thawed spermatozoa developed normally in vitro $(37 \%$ in $\mathrm{C} 57 \mathrm{BL} / 6 \mathrm{~N}$ to $71 \%$ in ICR) to the blastocyst stage and in vivo ( $19 \%$ for C57BL/6N spermatozoa and ddY oocytes) to Day 18 of gestation.
\end{abstract}

Keywords: mouse; spermatozoa; cryopreservation; pellet method; cryoprotectant; raffinose

\section{Introduction}

Since Polge \& Rowson (1952) first reported that glycerol could provide considerable protection to bull spermatozoa during freezing and thawing, there have been many reports on the cryopreservation of spermatozoa of various species including horse (Nishikawa et al., 1968), pig (Pursel \& Johnson, 1975), sheep (Colas, 1975), dog (Seager, 1969), rabbit (Fox, 1961), mouse (Graham et al., 1978, review), and man (Bunge \& Sherman, 1953). Such reports are limited to relatively large animals; there have been few reports for non-domestic animals such as rat and mouse.

We now report a simple and convenient method for cryopreservation of spermatozoa of normal and mutant mice.

\section{Materials and Methods}

Reagents. The cryoprotectants used were glycerol, raffinose, sucrose and dimethysulphoxide (DMSO), all purchased from Nakarai Chem. Co., Tokyo, Japan. The choice of concentration of each reagent was based upon the following papers; $7.0 \%$ giycerol, $10 \%$ sucrose and $18 \%$ raffinose were from Nagase (1966), and $10 \%$ DMSO was from O'Shea $\&$ Wales (1969). From these concentrations, the reagents were diluted serially and used for an assay.

Isolation of spermatozoa and treatments before freezing. Mouse spermatozoa were obtained from 5 inbred strains $(\mathrm{C} 57 \mathrm{BL} / 6 \mathrm{~N}, \mathrm{C} 3 \mathrm{H} / \mathrm{HeN}, \mathrm{BALB} / \mathrm{c}, \mathrm{kk}$ and $\mathrm{DBA} / 2 \mathrm{~N})$ and 2 strains of outbred mice (ddY and ICR). The kk mouse is 
known to be a human disease-model of spontaneous diabetes mellitus (Nakamura, 1962). All the inbred mice and ICR mice were purchased from CLEA JAPAN Inc., Tokyo, Japan. The ddY mice were obtained from Shizuoka Laboratory Animal Center, Shizuoka, Japan. Spermatozoa were isolated from each cauda epididymidis of a 10 -16-week-old male mouse by mincing them in a drop $(500 \mu \mathrm{l})$ of suspending medium covered with paraffin oil (Art. 7160, Merck, Darmstadt, FRG) in a tissue culture dish (Falcon 3001, Becton-Dickinson Co., Oxnard, CA, USA). The suspending medium consisted of physiological saline $(0.86 \% \mathrm{NaCl})$ and one or two cryoprotectant(s) at the concentration indicated. The spermatozoa were then allowed to disperse by standing the dish at room temperature for about $15 \mathrm{~min}$. After incubation, the cells were considered to be fully equilibrated. Sperm concentration was determined with a haemocytometer and each drop contained a minimum of $10^{6}$ spermatozoa. The extended semen was divided into two parts and handled as follows: one part was used for sperm freezing as described below, and the other was used for in-vitro fertilization, which serves as an unfrozen sperm control.

Freezing of spermatozoa. Spermatozoa were rapidly frozen by the pellet method (Nagase et al., 1972) with a slight modification. The semen $(250 \mu \mathrm{l})$, which had been extended with cryoprotectant-containing medium after isolation from the epididymis, was divided into 5 aliquants. Each sample $(50 \mu \mathrm{l})$ was then frozen as pellets in holes $(\sim 5 \mathrm{~mm}$ in diameter and $\sim 3 \mathrm{~mm}$ in depth) on a block of solid $\mathrm{CO}_{2}$ for $5 \mathrm{~min}$ or more. Each frozen pellet was then cooled in liquid nitrogen $\left(-196^{\circ} \mathrm{C}\right)$ for at least $5 \mathrm{~min}$, placed in a precooled cryotube (Nunc, Roskilde, Denmark) and finally stored at $-196^{\circ} \mathrm{C}$.

Spermatozoa were also frozen at a slower freezing rate with the aid of a programmed freezer (CRYOEMBRYO-HP, Hoxan Co., Sapporo, Japan): cells were cooled from 20 to $-5^{\circ} \mathrm{C}$ at $1^{\circ} \mathrm{C} / \mathrm{min}$ in a solution containing $7 \%$ glycerol, then left at $-5^{\circ} \mathrm{C}$ for $10 \mathrm{~min}$, and finally frozen through the two steps $\left(-5\right.$ to $-80^{\circ} \mathrm{C}$ at $8-10^{\circ} \mathrm{C} / \mathrm{min}$ and -80 to $-196^{\circ} \mathrm{C}$ at $\sim 800^{\circ} \mathrm{C} / \mathrm{min}$ ) by using plastic straws.

At thawing, spermatozoa were recovered with rapid warming in both cases: for cells frozen in pellets, a frozen pellet was added to a drop $(400 \mu \mathrm{l})$ of TYH medium (Toyoda et al., 1971) covered with paraffin oil pre-equilibrated with $5 \% \mathrm{CO}_{2}$ in air at $37^{\circ} \mathrm{C}$, and for cells frozen slowly, a plastic straw was immersed in hot water $\left(37^{\circ} \mathrm{C}\right)$ for 10 min and then $50 \mu \mathrm{l}$ solution containing spermatozoa were added to $400 \mu \mathrm{l}$ TYH medium as described above. After incubation for $10 \mathrm{~min}$ at $37^{\circ} \mathrm{C}$, the frozen-thawed spermatozoa were subjected to evaluation by assessment of motility and ability to fertilize in vitro.

Assessment of sperm motility. The percentage of actively motile spermatozoa (0-100\%) was assessed under a coverslip on a warm stage $\left(37^{\circ} \mathrm{C}\right)$ for $10 \mathrm{~min}$ after thawing. Over 200 spermatozoa were counted for each sample.

Assessment of sperm fertilizing ability. The in-vitro fertilization technique was as described by Toyoda et al. (1971). Unfertilized oocytes were obtained from all the strains of mice and an $\mathrm{F}_{1}$ hybrid mouse, $\mathrm{B} 6 \mathrm{C} 3 \mathrm{~F}_{1}$ (pairings of $\mathrm{C} 57 \mathrm{BL} /$ $6 \mathrm{~N} \times \mathrm{C} 3 \mathrm{H} / \mathrm{HeN}$, purchased from CLEA JAPAN Inc., Tokyo, Japan), aged 8-10 weeks. The females were induced to super-ovulate by intraperitoneal injection of 5 i.u. PMSG (Serotropin: Teikoku Zoki Co., Tokyo, Japan) and 5 i.u. hCG (Gestron: Denka Pharmaceutical Co., Kawasaki, Japan) given approximately $48 \mathrm{~h}$ apart. The females were killed 13-16 $\mathrm{h}$ after the administration of hCG, and their oviducts were removed and placed in a tissue culture dish (Falcon 3001) containing paraffin oil. The ampullae of the oviducts were torn open with dissecting needles and the oocytes with cumulus cells were placed into a drop $(400 \mu \mathrm{l})$ of TYH medium under paraffin oil equilibrated with $5 \%$ $\mathrm{CO}_{2}$ in air at $37^{\circ} \mathrm{C}$. The number of eggs per drop ranged from 10 to 30 . A $25-\mu$ l sample of frozen-thawed spermatozoa was added directly to the drop containing the oocytes.

In the control experiment, $50 \mu$ l suspending medium in which epididymal spermatozoa had been extended and equilibrated were removed, diluted with $450 \mu \mathrm{l}$ TYH medium and incubated for $10 \mathrm{~min}$ at $37^{\circ} \mathrm{C}$ under paraffin oil. Then, $25 \mu \mathrm{l}$ of this unfrozen sperm suspension was added to a drop of TYH medium containing oocytes. The drop contained a minimum of $10^{5}$ spermatozoa $/ \mathrm{ml}$.

The sperm - oocyte mixture was then cultured for up to $6 \mathrm{~h}$, by which time nearly all eggs had 2 pronuclei and the second polar body which were all visible by light microscopy. The eggs with two pronuclei and the second polar body were considered to be fertilized. Eggs that had totally degenerated, were unfertilized or exhibited abnormal morphology were removed.

In-vitro development of fertilized eggs to an early blastocyst stage. Oocytes from $F_{1}$ hybrid mice $\left(B_{6} 63 F_{1}\right)$ were inseminated in vitro for $6 \mathrm{~h}$ at $37^{\circ} \mathrm{C}$ with unfrozen or frozen-thawed spermatozoa as described above. Eggs that developed to the pronucleate stage were collected, transferred to drops $(400 \mu \mathrm{l})$ of Whitten's medium (Whitten, 1971) covered with paraffin oil on a tissue culture dish (Falcon 3001 ), and then cultured at $37^{\circ} \mathrm{C}$ for about $72 \mathrm{~h}$ up to the blastocyst stage in an humidified atmosphere of $5 \% \mathrm{CO}_{2}$ in air.

In-vivo development of in-vitro fertilized eggs beyond the blastocyst stage. The pronucleate stage eggs were transferred to the ampullary region of the oviduct of Day 1 pseudopregnant ICR females mated to a proven sterile vasectomized ICR male. Day 1 was the day on which the vaginal plug was formed. Fetuses that developed were inspected on Day 18 of pregnancy. 


\section{Results}

\section{Effects of cryoprotectants on the survival of frozen-thawed spermatozoa}

The effects of various cryoprotectants are shown in Table 1. When spermatozoa from ICR mice were extended in cryoprotectant-containing solution and then assessed for motility, more than $70 \%$ of cells were actively motile in each group, suggesting that none of reagents tested here is harmful to unfrozen mouse spermatozoa. However, when spermatozoa were recovered after freezing and thawing, only raffinose and sucrose afforded protection, as indicated by motility, but spermatozoa frozen with sucrose were incapable of fertilizing oocytes.

Table 1. Effects of cryoprotectants on the motility and the fertilizing ability of spermatozoa of ICR mice following freezing and thawing

\begin{tabular}{|c|c|c|c|c|}
\hline \multicolumn{2}{|c|}{ Cryoprotectants } & \multicolumn{2}{|c|}{ Motility $\dagger$} & \multirow[b]{2}{*}{$\begin{array}{c}\text { Fertilizing } \\
\text { ability } f\end{array}$} \\
\hline Name & $\begin{array}{l}\text { Final conc. }(\%) \\
\text { in suspending } \\
\text { medium }\end{array}$ & $\begin{array}{l}\text { Before } \\
\text { freezing }\end{array}$ & $\begin{array}{l}\text { After } \\
\text { freezing }\end{array}$ & \\
\hline Sucrose & $\begin{array}{r}10 \cdot 0 \\
5 \cdot 0 \\
2 \cdot 5\end{array}$ & $\begin{array}{l}80 \cdot 0 \pm 3 \cdot 5 \\
70 \cdot 0 \pm 3 \cdot 0 \\
73 \cdot 0 \pm 8 \cdot 4\end{array}$ & $\begin{array}{l}9.4 \pm 1.9 \\
4.4 \pm 1.3 \\
3.6 \pm 0.9\end{array}$ & $\begin{array}{l}0(0 / 21) \\
\text { N.D. } \\
\text { N.D. }\end{array}$ \\
\hline Raffinose & $\begin{array}{r}18 \cdot 0 \\
9 \cdot 0 \\
4 \cdot 5\end{array}$ & $\begin{array}{l}80 \cdot 4 \pm 2 \cdot 9 \\
81 \cdot 0 \pm 3 \cdot 1 \\
84 \cdot 0 \pm 2 \cdot 5\end{array}$ & $\begin{array}{l}43 \cdot 0 \pm 4 \cdot 5 \\
33 \cdot 2 \pm 4 \cdot 4 \\
33 \cdot 8 \pm 2 \cdot 8\end{array}$ & $\begin{array}{l}22.4(35 / 156)^{*} \\
16.8(19 / 113) \\
14.4(15 / 104)\end{array}$ \\
\hline $\begin{array}{l}\text { Dimethyl- } \\
\text { sulphoxide }\end{array}$ & $\begin{array}{r}10 \cdot 0 \\
5 \cdot 0 \\
2 \cdot 5\end{array}$ & $\begin{array}{l}79 \cdot 8 \pm 4.3 \\
84.6 \pm 3.4 \\
85.4 \pm 1.8\end{array}$ & $\begin{array}{l}0 \\
0 \\
0\end{array}$ & $\begin{array}{l}0(0 / 25) \\
\text { N.D. } \\
\text { N.D. }\end{array}$ \\
\hline Glycerol & $\begin{array}{l}7 \cdot 0 \\
3 \cdot 5 \\
1 \cdot 75\end{array}$ & $\begin{array}{l}80 \cdot 2 \pm 1 \cdot 8 \\
80 \cdot 4 \pm 1 \cdot 5 \\
80 \cdot 0 \pm 3 \cdot 5\end{array}$ & $\begin{array}{l}0 \\
0 \\
0\end{array}$ & $\begin{array}{l}0(0 / 37) \\
\text { N.D. } \\
\text { N.D. }\end{array}$ \\
\hline $\begin{array}{l}\text { Raffinose } \\
\text { + Glycerol } \\
\text { + Glycerol } \\
\text { + Glycerol }\end{array}$ & $\begin{array}{c}18 \cdot 0 \\
7 \cdot 0 \\
3 \cdot 5 \\
1 \cdot 75\end{array}$ & $\begin{array}{l}80 \cdot 6 \pm 1 \cdot 9 \\
78 \cdot 8 \pm 2 \cdot 9 \\
79 \cdot 2 \pm 2 \cdot 9\end{array}$ & $\begin{array}{l}33.6 \pm 4.7 \\
50 \cdot 6 \pm 2.6 \\
61.4 \pm 2.6\end{array}$ & $\begin{array}{c}11.4(18 / 158) \\
9 \cdot 0(17 / 189) \\
35 \cdot 5(87 / 245)^{*}\end{array}$ \\
\hline
\end{tabular}

†Values are mean \pm s.e.m. percentages for 5 determinants.

$\ddagger$ Values are percentages, based upon data over 5 replicates (14-41 eggs/treatment), with the ratio of the no. of fertilized eggs to the total no. of eggs examined in parentheses.

N.D. $=$ not determined.

${ }^{*} P<0.05\left(\chi^{2}\right.$ test $)$.

When spermatozoa were frozen in the presence of $18 \%$ raffinose and various amounts of glycerol, a higher fertilization rate was obtained with $18 \%$ raffinose and $1.75 \%$ glycerol (Table 1 ).

\section{Fertilizing ability of frozen-thawed mouse spermatozoa from different strains of mice}

The mixture of raffinose (18\%) and glycerol $(1.75 \%)$ was tested with spermatozoa from strains other than ICR mice. As shown in Table 2, most of the spermatozoa exhibited active motility (over $65 \%$ ) before freezing, but after freezing and thawing sperm motility was reduced to $30-60 \%$ for each strain. There were strain differences in fertilizing ability among unfrozen spermatozoa and frozen-thawed cells, but the patterns differed from that in the unfrozen sperm group. 
Table 2. Comparison of motility and fertilizing ability of spermatozoa from several strains of mouse before freezing and after freezing and thawing

\begin{tabular}{|c|c|c|c|c|c|}
\hline \multicolumn{2}{|c|}{ Gametes } & \multicolumn{2}{|c|}{ Frozen -thawed spermatozoa } & \multicolumn{2}{|c|}{ Unfrozen spermatozoa } \\
\hline Spermatozoa & Oocytes & $\begin{array}{c}\text { Motility } \\
(\%) \dagger\end{array}$ & $\begin{array}{c}\text { Fertilizing } \\
\text { ability }\end{array}$ & $\begin{array}{c}\text { Motility } \\
(\%) \dagger\end{array}$ & $\begin{array}{c}\text { Fertilizing } \\
\text { ability }\end{array}$ \\
\hline $\mathrm{C} 57 \mathrm{BL} / 6 \mathrm{~N}$ & $\mathrm{C} 57 \mathrm{BL} / 6 \mathrm{~N}$ & $37 \cdot 1 \pm 4 \cdot 9$ & $12.9(11 / 85)^{\mathrm{c}}$ & $76 \cdot 7 \pm 5 \cdot 8$ & $60 \cdot 9(42 / 69)$ \\
\hline $\mathrm{BALB} / \mathrm{c}$ & $\mathrm{BALB} / \mathrm{c}$ & $35 \cdot 0 \pm 5 \cdot 5$ & $18.9(20 / 106)^{\mathrm{a}}$ & $73 \cdot 3 \pm 5 \cdot 8$ & $39 \cdot 1(18 / 46)$ \\
\hline $\mathrm{DBA} / 2 \mathrm{~N}$ & $\mathrm{DBA} / 2 \mathrm{~N}$ & $33 \cdot 3 \pm 5 \cdot 2$ & $63 \cdot 5(80 / 126)^{\mathrm{b}}$ & $77 \cdot 5 \pm 5 \cdot 0$ & $91 \cdot 9(34 / 37)$ \\
\hline $\mathrm{C} 3 \mathrm{H} / \mathrm{HeN}$ & $\mathrm{C} 3 \mathrm{H} / \mathrm{HeN}$ & $39 \cdot 5 \pm 1 \cdot 6$ & $35 \cdot 0(62 / 177)^{c}$ & $67 \cdot 5 \pm 9 \cdot 6$ & $71 \cdot 7(38 / 53)$ \\
\hline $\mathrm{kk}$ & kk & $33 \cdot 0 \pm 4 \cdot 8$ & $31 \cdot 5(35 / 111)^{\mathrm{c}}$ & $72 \cdot 5 \pm 5 \cdot 0$ & $96 \cdot 1(49 / 51)$ \\
\hline $\mathrm{dd} Y$ & dd $Y$ & $45 \cdot 0 \pm 5 \cdot 5$ & $47 \cdot 9(23 / 48)^{\mathrm{b}}$ & $79 \cdot 0 \pm 2 \cdot 2$ & $80 \cdot 0(24 / 30)$ \\
\hline ICR & ICR & $56 \cdot 0 \pm 8 \cdot 4$ & $35.5(87 / 245)^{b}$ & $78 \cdot 8 \pm 2 \cdot 5$ & $95 \cdot 1(174 / 183)$ \\
\hline
\end{tabular}

$\dagger$ Mean \pm s.e.m. percentages for over 4 determinations.

${ }_{4}^{\dagger}$ Percentages, based upon data averaged from over 4 replicates, with the ratio of the no. of fertilized eggs to the total no. of eggs examined in parentheses.

${ }^{\mathrm{a}} P<0.05 ;{ }^{\mathrm{b}} P<0.01{ }^{\mathrm{c}} P<0.001$ compared with unfrozen spermatozoa $\left(\chi^{2}\right.$ test $)$.

\section{Survival of mouse eggs fertilized by frozen-thawed spermatozoa beyond the pronucleate stage up to term}

$\mathrm{F}_{1}$ hybrid $\left(\mathrm{B} 6 \mathrm{C} 3 \mathrm{~F}_{1}\right)$ oocytes were used because they were known to be capable of developing more frequently to the blastocyst stage in vitro than those from many pure strains (Parkening $e t$ al., 1976). In almost all tests, the percentage of pronucleate stage $F_{1}$ hybrid eggs that had been fertilized by frozen-thawed spermatozoa and developed to the blastocyst stage was significantly less than that of eggs fertilized by unfrozen spermatozoa (Table 3), although all eggs were considered to be fertilized at the start of culture. The blastocysts developed from eggs fertilized by unfrozen and by frozen-thawed spermatozoa had normal morphology.

Table 3. Comparison of in-vitro development of eggs fertilized by frozen-thawed and unfrozen spermatozoa in mice

\begin{tabular}{|c|c|c|c|c|c|}
\hline \multicolumn{2}{|c|}{ Gametes } & \multicolumn{2}{|c|}{ Frozen-thawed spermatozoa } & \multicolumn{2}{|c|}{ Unfrozen spermatozoa } \\
\hline Spermatozoa & Oocytes & $\begin{array}{l}\text { Fertilizing } \\
\text { ability }{ }^{\dagger}\end{array}$ & $\begin{array}{l}\text { Developmental } \\
\text { rate } \ddagger\end{array}$ & $\begin{array}{l}\text { Fertilizing } \\
\text { ability }{ }^{\dagger}\end{array}$ & $\begin{array}{c}\text { Developmental } \\
\text { rate }\end{array}$ \\
\hline $\mathrm{C} 57 \mathrm{BL} / 6 \mathrm{~N}$ & $\mathrm{~B}_{6} \mathrm{C} 3 \mathrm{~F}_{1}$ & $35.4(79 / 223)^{\mathrm{c}}$ & $36.7(29 / 79)^{\varepsilon}$ & $76 \cdot 5(52 / 68)$ & $73 \cdot 1(38 / 52)$ \\
\hline $\mathrm{BALB} / \mathrm{c}$ & $\mathrm{B} 6 \mathrm{C} 3 \mathrm{~F}_{1}$ & $38 \cdot 7(58 / 150)^{\mathrm{a}}$ & $46 \cdot 6(27 / 58)^{b}$ & $52 \cdot 3(57 / 109)$ & $75.4(43 / 57)$ \\
\hline $\mathrm{C} 3 \mathrm{H} / \mathrm{HeN}$ & $\mathrm{B} 6 \mathrm{C} 3 \mathrm{~F}_{1}$ & $36 \cdot 0(50 / 139)^{\mathrm{c}}$ & $40 \cdot 0(20 / 50)^{\mathrm{C}}$ & $77.6(59 / 76)$ & $76 \cdot 3(45 / 59)$ \\
\hline $\mathrm{DBA} / 2 \mathrm{~N}$ & $\mathrm{~B} 6 \mathrm{C} 3 \mathrm{~F}_{1}$ & $62 \cdot 8(76 / 121)^{\mathrm{c}}$ & $51 \cdot 3(39 / 76)^{\mathrm{e}}$ & $88 \cdot 4(130 / 147)$ & $80.9(89 / 110)$ \\
\hline kk & $\mathrm{B}_{6} \mathrm{C} 3 \mathrm{~F}_{1}$ & $41 \cdot 4(58 / 140)^{\mathrm{c}}$ & $44.4(20 / 45)^{b}$ & $85 \cdot 2(69 / 81)$ & $73 \cdot 0(46 / 63)$ \\
\hline dd $Y$ & $\mathrm{~B} 6 \mathrm{C} 3 \mathrm{~F}_{1}$ & $41 \cdot 7(75 / 180)^{c}$ & $39 \cdot 6(21 / 53)^{\mathrm{c}}$ & $87 \cdot 5(56 / 64)$ & $85 \cdot 7(48 / 56)$ \\
\hline ICR & $\mathrm{B}_{6} \mathrm{C} 3 \mathrm{~F}_{1}$ & $34-5(51 / 148)^{\mathrm{c}}$ & $70 \cdot 6(36 / 51)^{a}$ & $72 \cdot 2(78 / 108)$ & $84 \cdot 0(63 / 75)$ \\
\hline
\end{tabular}

†Values are percentages, based upon data averaged from at least 5 replicates, with the ratio of the no. of fertilized eggs to the total no. of eggs examined in parentheses.

‡Values are percentages, based upon data averaged from at least 5 replicates, with the ratio of the no. of blastocysts to the total no. of eggs cultured in parentheses.

${ }^{\mathrm{a}} P>0.05 ;{ }^{\mathrm{b}} P<0.01 ;{ }^{\mathrm{c}} P<0.001$ compared with values for unfrozen spermatozoa $\left(\chi^{2}\right.$ test).

When $57 \mathrm{ddY}$ eggs, which had been fertilized by unfrozen or frozen-thawed spermatozoa from C57BL/6N mice and cultured for $6 \mathrm{~h}$, were transferred into the oviducts of pseudopregnant mice (Table 4), some eggs developed normally to viable fetuses. 
Table 4. Development in utero of ddY mouse eggs fertilized in vitro by frozen-thawed and unfrozen epididymal spermatozoa (C57BL/6N)

\begin{tabular}{lcccc}
\hline & \multicolumn{4}{c}{$\begin{array}{c}\text { Inspection on } \\
\text { Day 18 of gestation }\end{array}$} \\
\cline { 3 - 4 } Spermatozoa & $\begin{array}{c}\text { No. of eggs } \\
\text { transferred } \\
\text { (recipients) }\end{array}$ & $\begin{array}{c}\text { Implantation } \\
\text { residue }\end{array}$ & $\begin{array}{c}\text { Live } \\
\text { fetuses }\end{array}$ & $\begin{array}{c}\text { Overall } \\
\text { survival } \\
\text { rate* }\end{array}$ \\
\hline Frozen-thawed & $57(3)$ & 0 & 11 & $19 \cdot 3$ \\
Unfrozen & $104(5)$ & 2 & $4 !$ & $39 \cdot 5$ \\
\hline
\end{tabular}

$* P<0.05\left(\chi^{2}\right.$ test $)$

\section{Discussion}

Glycerol has been widely utilized as a cryoprotectant for frozen storage of spermatozoa of several mammals, including bull (Polge \& Rowson, 1952), a dog (Seager, 1969), sheep (Colas, 1975), horse (Nishikawa et al., 1968) and pig (Pursel \& Johnson, 1975). However, in our experiment in which ICR mouse spermatozoa were frozen by a rapid two-step freezing method, glycerol did not afford protection to the cells at any concentration so far tested. There are several possible explanations for this failure: (1) insufficient equilibration of spermatozoa with cryoprotectants may be the cause because the cells may have had too much intracellular water at the time of freezing and, therefore, did not survive the freezing insult; (2) inappropriate freezing may lead to such failure; (3) such a phenomenon may be a reflection of the differences in the resistance to a freezing and thawing among the cells of different species. In a preliminary experiment in which epididymal ICR spermatozoa were extended in a solution containing $7.0 \%$ glycerol for 15,30 and $45 \mathrm{~min}$, and then frozen as pellets, there was no cell survival after thawing. Longer equilibration of spermatozoa with glycerol therefore does not seem to improve sperm cryosurvival. In other species (Nagase, 1966) glycerol may provide adequate protection at slower freezing rates, while sugars protect at very fast freezing rates. In our rapid freezing system, therefore, glycerol would not be expected to be effective for cryoprotection to spermatozoa. However, glycerol was not effective even at a slower freezing rate (data not shown). The second possibility is therefore also unlikely. The third explanation seems to be the most likely, although we do not yet have supporting data. As shown in the present study, both DBA/2N and kk spermatozoa exhibited almost the same fertilization rates $(91.9$ and $96 \cdot 1 \%$, respectively) before freezing, while after freezing and thawing fertilization rates of DBA/ $2 \mathrm{~N}$ and kk cells were reduced to 63.5 and $31.5 \%$, respectively. Our present results showed that glycerol alone did not provide any protection of mouse spermatozoa, but addition of $1.75 \%$ glycerol to the raffinose $(18 \%)$-containing diluent improved the fertilizing ability of frozen-thawed spermatozoa. The mechanism by which glycerol works as a cryoprotectant with raffinose in mice remains to be investigated.

Although spermatozoa were successfully frozen as pellets after treatment with a mixture of raffinose and glycerol, the percentage of oocytes fertilized by frozen-thawed spermatozoa was significantly lower than that of oocytes fertilized by unfrozen cells (see Table 2). This suggests that the frozen-thawed spermatozoa consist of totally normal cells and cells with various degrees of defectiveness. It will be necessary to enrich actively motile spermatozoa after freezing and thawing to test whether the enriched cells can increase the fertilization rate to the same level as unfrozen spermatozoa.

Mouse spermatozoa have been successfully frozen (by Rapatz \& Zimmerman; see review by Graham et al., 1978). In that study, mouse epididymal spermatozoa were suspended in a skim milk medium ( $10.5 \%$ solids) containing $0.75 \%$ fructose, $1 \%$ bovine serum albumin and 4 mm-calcium chloride and then frozen. After thawing and subsequent artificial insemination of the frozen- 
thawed spermatozoa, 9 out of 84 females gave birth to 61 young ( 6.9 per litter). Further comparison of the two methods is not possible, but investigation of developmental ability in mouse eggs resulting from fertilization by spermatozoa frozen in the solution mentioned above and transferred to the oviducts as in our study would be of interest.

In this study, we showed that freezing and thawing potentially affected the function of spermatozoa in post-fertilization events when some eggs resulting from fertilization by frozenthawed spermatozoa failed to develop further in vitro and in vivo (see Tables 3 and 4). Such early embryonic death has also been shown in rabbits by Maurer et al. (1976). This may be due to a reduced penetration rate by the frozen-thawed spermatozoa, and in turn to ageing of the unfertilized oocytes and hence reduced viability of eggs. Failure of sperm capacitation in frozen-thawed cells may also affect post-fertilization development of eggs as well as initial fertilization.

The method we describe is now routinely used for storing spermatozoa of various inbred mouse strains, mutant mice and transgenic mice in our laboratory. The numbers of transgenic mice are increasing day by day but much molecular analysis remains to be done. We believe our system for freezing mouse spermatozoa will be useful in the field of mouse molecular genetics in the future.

We thank Dr T. Sakaguchi for his encouragement during this work.

\section{References}

Bunge, R.G. \& Sherman, J.K. (1953) Fertilizing capacity of frozen human spermatozoa. Nature, Lond. 172, $767-768$.

Colas, G. (1975) Effect of initial freezing temperature, addition of glycerol and dilution on the survival and fertilizing ability of deep-frozen ram semen. $J$. Reprod. Fert. 42, 277-285.

Fox, R.R. (1961) Preservation of rabbit spermatozoa: fertility results from frozen semen. Proc. Soc. exp. Biol. Med. 108, 663.

Graham, E.F., Schmehl, M.K., Evensen, B.K. \& Nelson, D.S. (1978) Semen preservation in non-domestic mammals. Symp. zool. Soc. Lond. 43, 153-173.

Maurer, R.R., Stranzinger, G.F. \& Paufler, S.K. (1976) Embryonic development in rabbits after insemination with spermatozoa stored at 37,5 or $-196^{\circ} \mathrm{C}$ for various periods. J. Reprod. Fert. 48, 43-49.

Nagase, H. (1966) Cryoprotective effect of sugars to bull spermatozoa. Jap. J. Anim. Reprod., Suppl. 1, 2-11.

Nagase, H., Tomizuka, T., Hanada, A., Hosoda, T. \& Morimoto, H. (1972) Cryoprotection of some amide solutes to spermatozoa of domestic animals. I. Effects of formamide, acetamide and lactamide on the motility of bovine spermatozoa in pellet freezing. Jap. J. Anim. Reprod. 18, 15-21. [In Japanese.]

Nakamura, M. (1962) A diabetic strain of the mouse. Proc. Jap. Acad. 38, 348-352.
Nishikawa, Y., Waide, Y. \& Shinomiya, S. (1968) Studies of deep freezing of horse spermatozoa. Proc. 6th Int. Congr. Anim. Reprod. \& A.I., Paris 2, 1589-1591.

O'Shea, T. \& Wales, R.G. (1969) Further studies on the deep freezing of rabbit spermatozoa in reconstituted skim milk powder. Aust. J. biol. Sci. 22, 709-719.

Parkening, T.A., Tsunoda, Y. \& Chung, M.C. (1976) Effects of various low temperature, cryoprotective agents and cooling rates on the survival, fertilizability and development of frozen-thawed mouse eggs. $J$. exp. Zool. 197, 369-374.

Polge, C. \& Rowson, L.E.A. (1952) Fertilizing capacity of bull spermatozoa after freezing at $-79^{\circ} \mathrm{C}$. Nature, Lond. 169, 626627.

Pursel, V.G. \& Johnson, L.A. (1975) Freezing of boar spermatozoa; fertilizing capacity with concentrated semen and a new thawing procedure. J. Anim. Sci.40, 99-102.

Seager, S.W. (1969) Successful pregnancies utilizing frozen dog semen. A.l. Digest 17, 6-10.

Toyoda, Y., Yokoyama, M. \& Hoshi, T. (1971) Studies on the fertilization of mouse eggs in vitro. I. In-vitro fertilization of eggs by fresh epididymal sperm. Jap. J. Anim. Reprod. 16, 147-151.

Whitten, W.K. (1971) Nutrient requirements for the culture of pre-implantation embryos. Adv. Biosci. 6, 129-139.

Received 26 September 1989 